\title{
THE MONTHLY UNEMPLOYMENT RATE IN REGIONS: EMPIRICAL EVIDENCE FROM THE VISEGRAD GROUP COUNTRIES
}

\section{MĚSÍČNÍ MÍRA NEZAMĚSTNANOSTI V REGIONECH: EMPIRICKÁ EVIDENCE ZE ZEMÍ VISEGRÁDSKÉ ČTYŘKY}

\author{
Mgr. Ing. Michal TVRDON, Ph.D. \\ Katedra ekonomie $\mid$ Department of Economics \\ Obchodně podnikatelská fakulta v Karviné School of Business Administration in Karvina \\ Slezská univerzita v Opavě Silesian University in Opava \\ $\bowtie$ Univerzitní nám. 1934/3, 73340 Karviná, Czech Republic \\ E-mail:tvrdon@opf.slu.cz
}

\begin{abstract}
Annotation
Paper deals with the development of the unemployment rate in Visegrad group's regions. Aim of this paper is to evaluate trends in regional disparities at the selected administrative levels during the period 2005-2012. Monthly data were applied for an analysis. These data were collected from national labour market authorities. From the analysis we can see remarkable differences between the regions. Moreover, regional unemployment disparities across Visegrad group countries appear to be characterized by a high degree of persistence. Calculations also confirmed a link between the business cycle and changes in regional disparities.

\section{Key words}

regional disparities, unemployment rate, Visegrad group

\section{Anotace}

Článek se zabývá vývojem míry nezaměstnanosti v regionech Visegrádské skupiny. Cílem je zhodnotit trendy ve vývoji regionálnich disparit ve vybraných administrativnich úrovnich během obdobi let 2005-2012. V článku byly využity měsični údaje o míre nezaměstnanosti na regionální úrovni. Tyto údaje byly získány z národnich orgánů vedoucich statistiku trhu práce. Z analýzy jsou patrné významné rozdíly mezi regiony. Navic, rozdilly v nezaměstnanosti napřič zemémi Visegrádské skupiny přetrvávaji. Ziskaná data také potvrdila obecně známou souvislost mezi vývojem hospodárského cyklu a změnou regionálnich rozdilì.
\end{abstract}

\section{Klíčová slova}

míra nezaměstnanosti, regionální disparity, Visegrádská skupina

JEL classification: $J 14$, R10

\section{Introduction}

The analysis of regional disparities in the European Union has become a popular theme in the last two decades. The New Member States were converging significantly during the years 2004-2008. This convergence process was characterized by real gross domestic product growth. As the labour market performance is influenced by the business cycle, better economic performance was associated with reduction in the unemployment rate at the national level. However, the question is if this process was conducted also at the regional level. In this paper, we try to explain the extent to which existing regional disparities on the labour market in the Visegrad Group countries (Czech Republic, Hungary, Poland and Slovak Republic) can be attributed to differences in levels of the unemployment rates. 
The aim of this paper is to evaluate trends in regional disparities at the selected administrative levels during the period 2005-2012. Based on the results obtained, we assessed and compared the level of achieved regional imbalances. We used national databases for our analysis. The reason why we did not apply the Eurostat database is that it does not contain monthly regional data.

\section{Empirical Results}

In this paper, we used data from national labour market authorities' databases. Regions are divided, based on the Eurostat's methodology NUTS, into three territorial levels: (i) NUTS 1 territorial unit as major regional countries; (ii) NUTS 2 territorial unit which usually corresponds to the level of lower level of the administrative division and (iii) NUTS 3 territorial unit which generally corresponds to the lowest administrative level. We used data at the relevant administrative level - "kraj" for the Czech Republic (14 regions at the NUTS 3 level), "kraj" for the Slovak Republic (8 regions at the NUTS 3 level), "megye" for Hungary (19 regions at the NUTS 3 level) and "województwo" for Poland (16 regions at the NUTS 2 level). As seen above NUTS 3 territorial level corresponds in three out of four cases (Poland is exception) to natural administrative units in V4 countries with their own regional government. While in Hungary, the Czech Republic and Slovakia the NUTS 3 regions are essential administrative regional units (counties or regions) in case of Poland they are called sub-regions, which are artificially created regions resulting from the merger of several districts. Concerning the level of NUTS 2 regions which are important for allocation of EU Structural Funds the situation is reversed. While in Poland they are the basic regional administrative units (provinces) with their own government for the rest of V4 countries NUTS 2 level or so called cohesion regions are only a purposeful combination of 1 to 3 administrative NUTS 3 regions due to the allocation of EU Structural Funds.

Fig. 1:Development of the national unemployment rate in the Visegrad group, monthly data 20052012

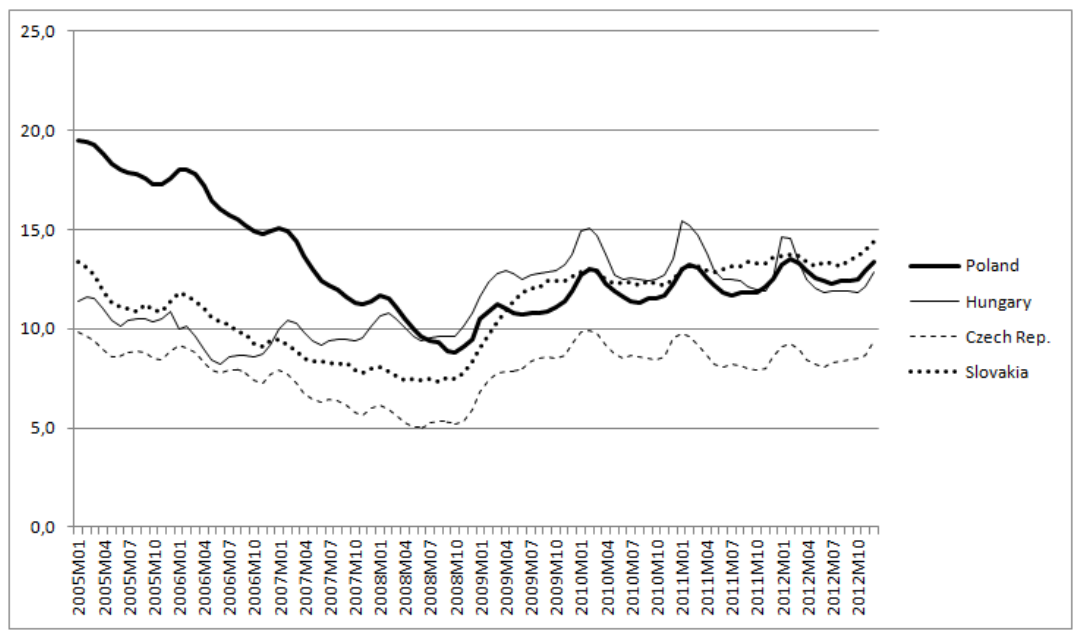

Source: National labour market authorities

Figure 1 shows development of the unemployment rate at the national level in Visegrad group. The global recession resulted in a severe shock to the Visegrad Group countries. Moreover, both Czech and Slovakia economy got even beyond its potential in the first half of 2008, which in conjunction with a public finance reform caused inter alia by a rise of the inflation rate. The recession's consequences were: the number of unemployed rose, employment declined and many employees are working fewer hours than before the crisis. However, unemployment rate development in the observed countries was different. While the unemployment rate was decreasing until the beginning of the economic crisis Poland, Czech Republic and Slovakia, in Hungary, the unemployment rate was stagnating - Hungary was in serious macroeconomic problems of a fiscal nature in this period, which had a great influence on the catching up process which was accompanied by a process of rapid catchup growth in regional imbalances. 
If we look at labour market development in the Czech regions we can see that some regions were below the national average and some were above this average (see Figure 2 - regions with similar or lower unemployment rates in comparison with the national one are on the left side of the figure and regions with the higher unemployment rates are on the right side of the figure). However, we found one common feature - the registered unemployment rate was decreasing sharply in all regions until the October 2008. Thereafter it was followed by a sharp deterioration in labour market performance, and the unemployment rate has returned to a high level within four months. Although the remarkable decrease of the unemployment rate has been recorded in the problematic regions Ústecký and Moravskoslezský kraj since the year 2005, the number of unemployed has stayed higher in these regions in comparison with other regions and it means a longstanding problem of highly regionalized structural unemployment.

Fig. 2: Regional unemployment rate in the Czech Republic, monthly data 2005-2012
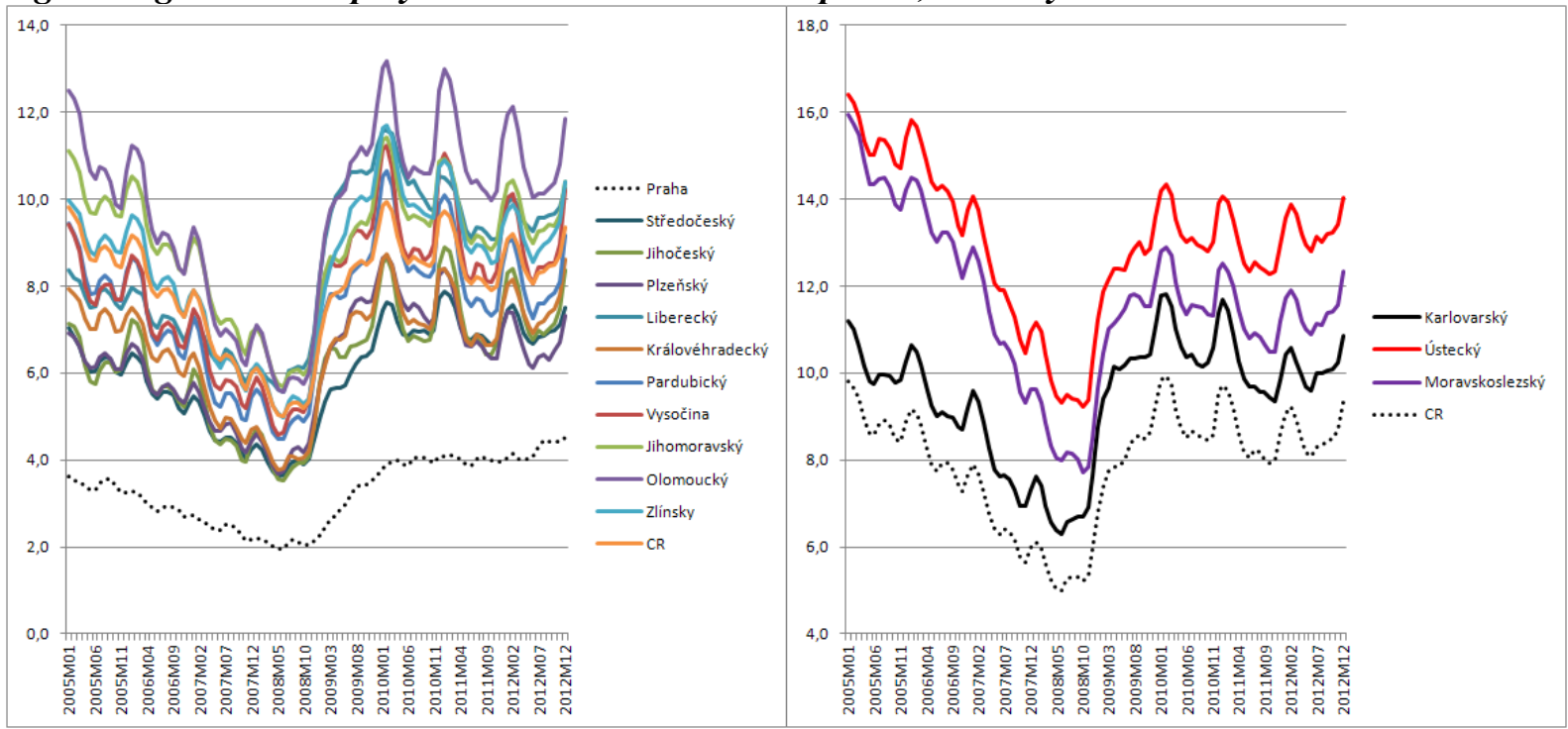

Source: Czech Ministry of Labour and Social Affairs

Fig. 3: The minimum and maximum range of regional unemployment rate in the Czech Republic

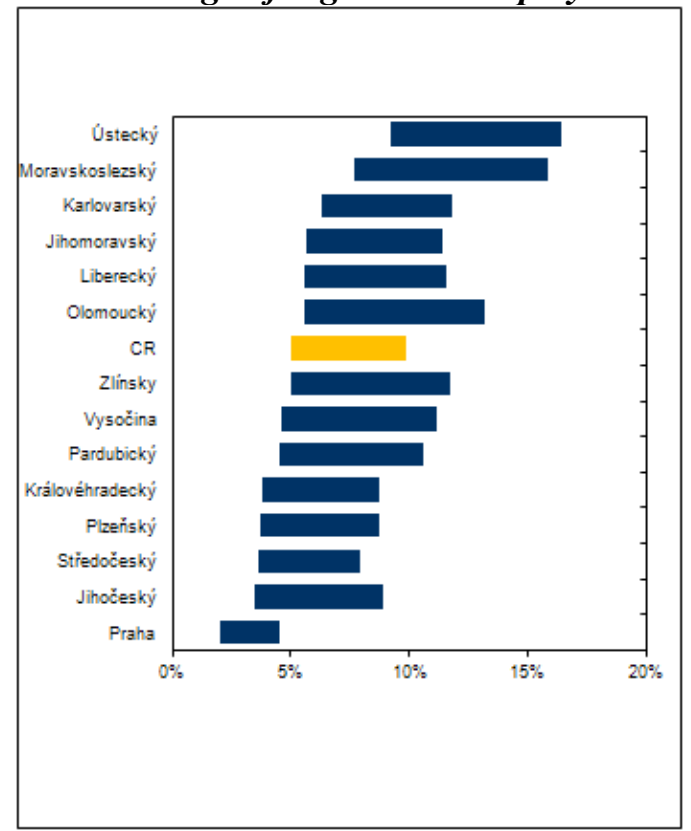

Source: Czech Ministry of Labour and Social Affairs 
The Figure 3 shows the range of minimum and maximum levels of unemployment, which was reached in the observed period. As seen from figure, the highest difference was reached in case of Ústecký, Moravskoslezský and Olomoucký regions. The highest unemployment rate was also recorded in these three regions. On the other side, low difference between the lowest and highest unemployment rate was reached in the region of the capital city Praha. This suggests a conclusion that labour supply is more stable in this region and it is not so sensitive to the business cycle.

Labour market development in Slovakia was similar (see Figure 4) - the lowest unemployment in comparison with the national level existed in the Bratislavsky region. In addition, we can find more regions with lower unemployment rate - Trenčianský, Trnavský, Nitrianský and Žilinský region. On the other hand, there were three regions with significant problems associated with labour market performance. These problems are reflected in particular by the fact that the highest unemployment was reached within the Visegrad group's regions. Moreover, last data indicate that the situation might get worse.

Fig. 4: Regional unemployment rate in Slovakia, monthly data 2005-2012

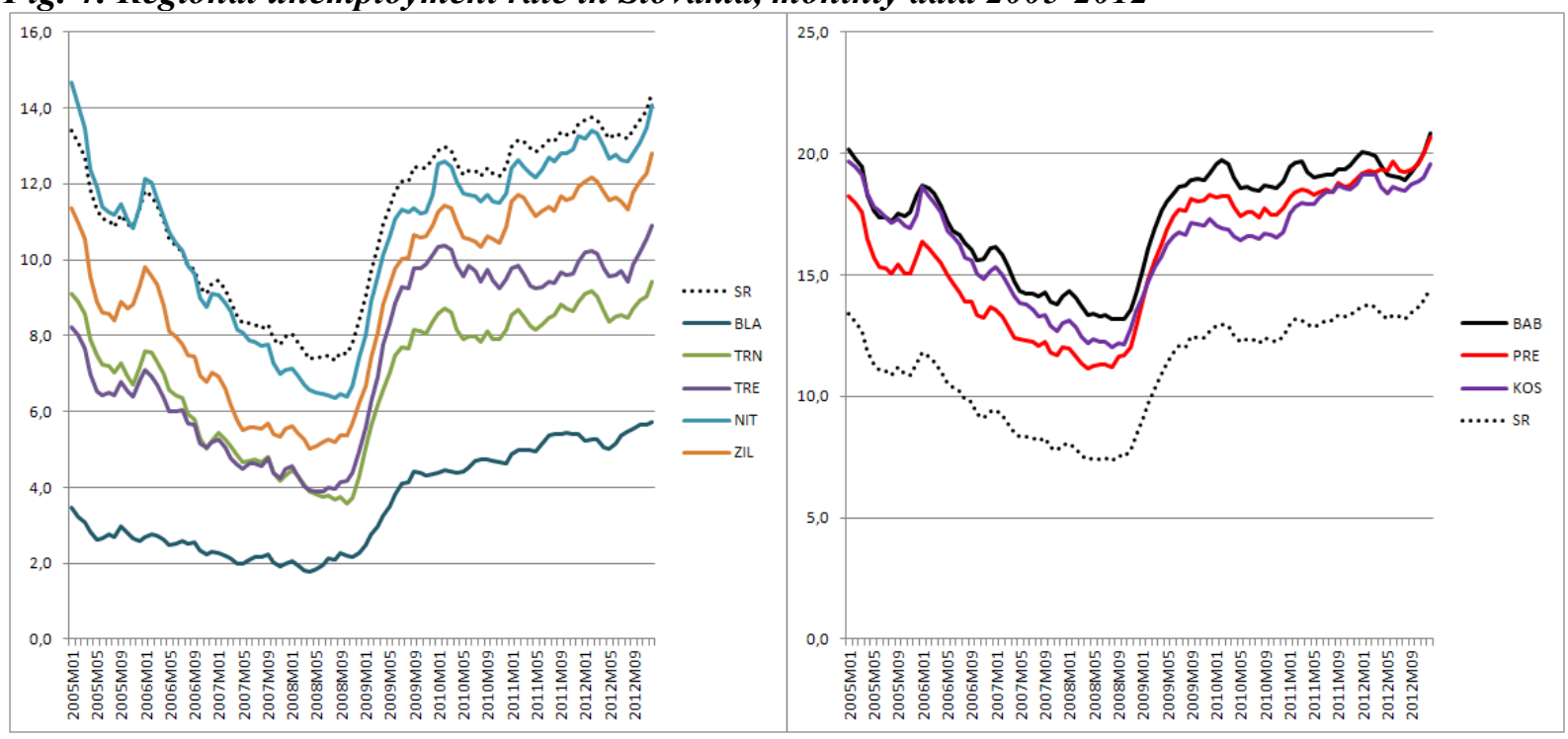

Source: Ministry of Labour, Social Affairs and Family of the Slovak Republic

If we look at a range between reached minimum and maximum, the situation is the same as in the Czech Republic. The only difference lies in the fact that the values are shifted to the right, in other words it means that the values are higher.

\section{Fig. 5: The minimum and maximum range of regional unemployment rate in Slovakia}

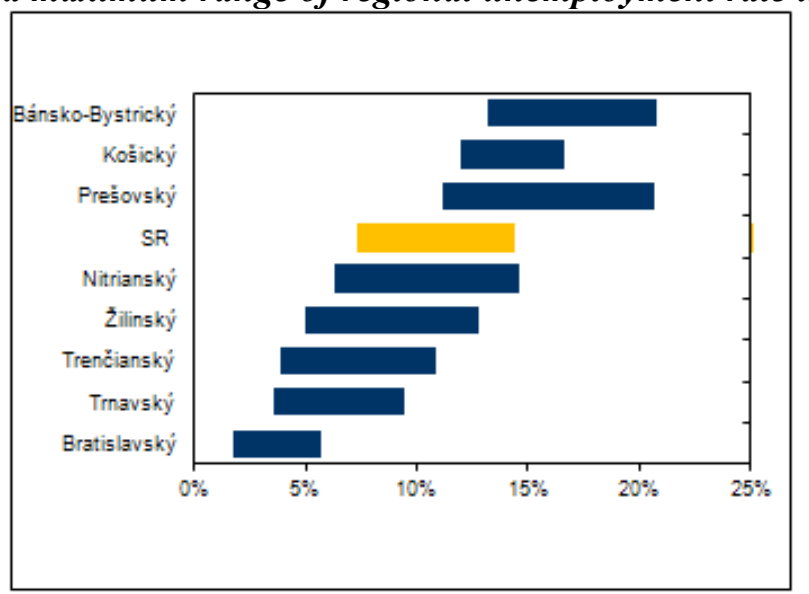

Source: Ministry of Labour, Social Affairs and Family of the Slovak Republic 
Fig. 6: Regional unemployment rate in Hungary, monthly data 2005-2012

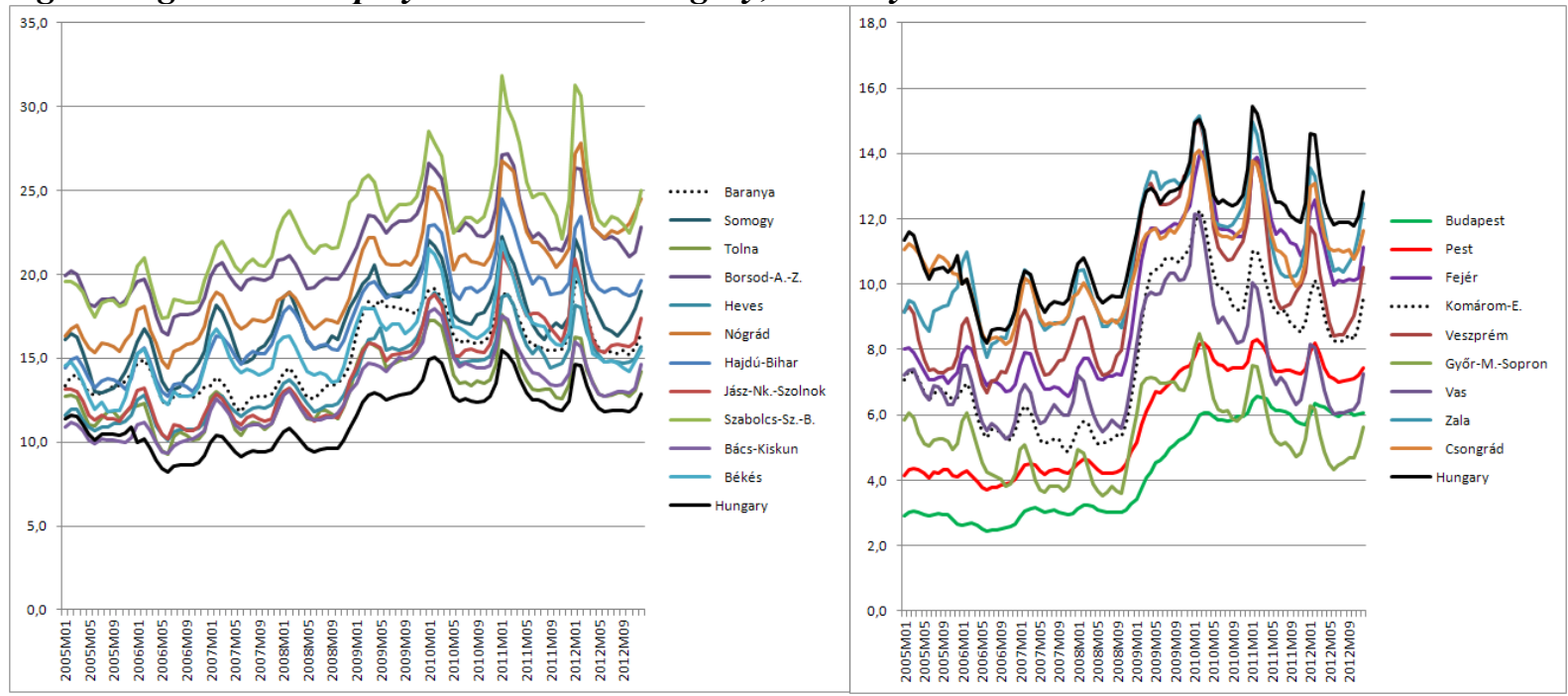

Source: Hungarian Ministry of Social Affairs and Labour

Different labour market development was observed in the case of Hungary. Unlike other Visegrad group countries there was a sharp decline in the unemployment rate in the pre-crisis period. This insufficient labour market development was influenced by bad economic situation in the country which was caused by unstable finances, large fiscal imbalances and high government debt. Given the size of fiscal imbalances, government had to raise state budget's revenues, e.g. hikes in employee social contributions, value-added tax and business taxation (Tvrdon, 2011). As in other Visegrad group countries we can find regions with lower unemployment rate compared with the national level and vice versa. The region with the remarkably lower unemployment rate was the region of the capital city (see Figure 6).

Fig. 7: The minimum and maximum range of regional unemployment rate in Hungary

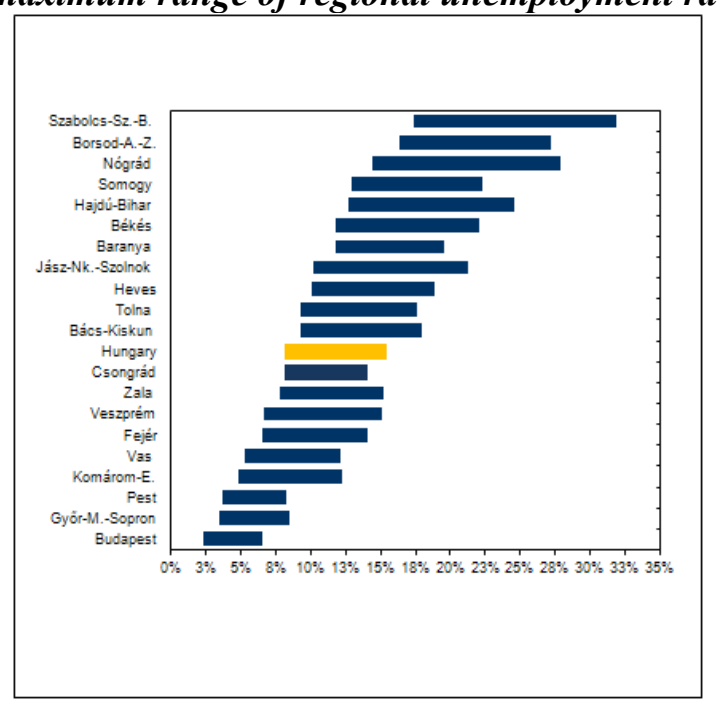

Source: Hungarian Ministry of Social Affairs and Labour

We consider a serious problem high value of the maximum in the case of some regions. This value exceeded $30 \%$. In our point of view in regions with so high unemployment rate must be introduced some structural changes to increase competitiveness - higher unemployment rate in these regions means also lower competitiveness (for more detailed analysis see Muntean, Nistor and Nistor, 2010). 
Fig. 8: Regional unemployment rate in Poland, monthly data 2005-2012

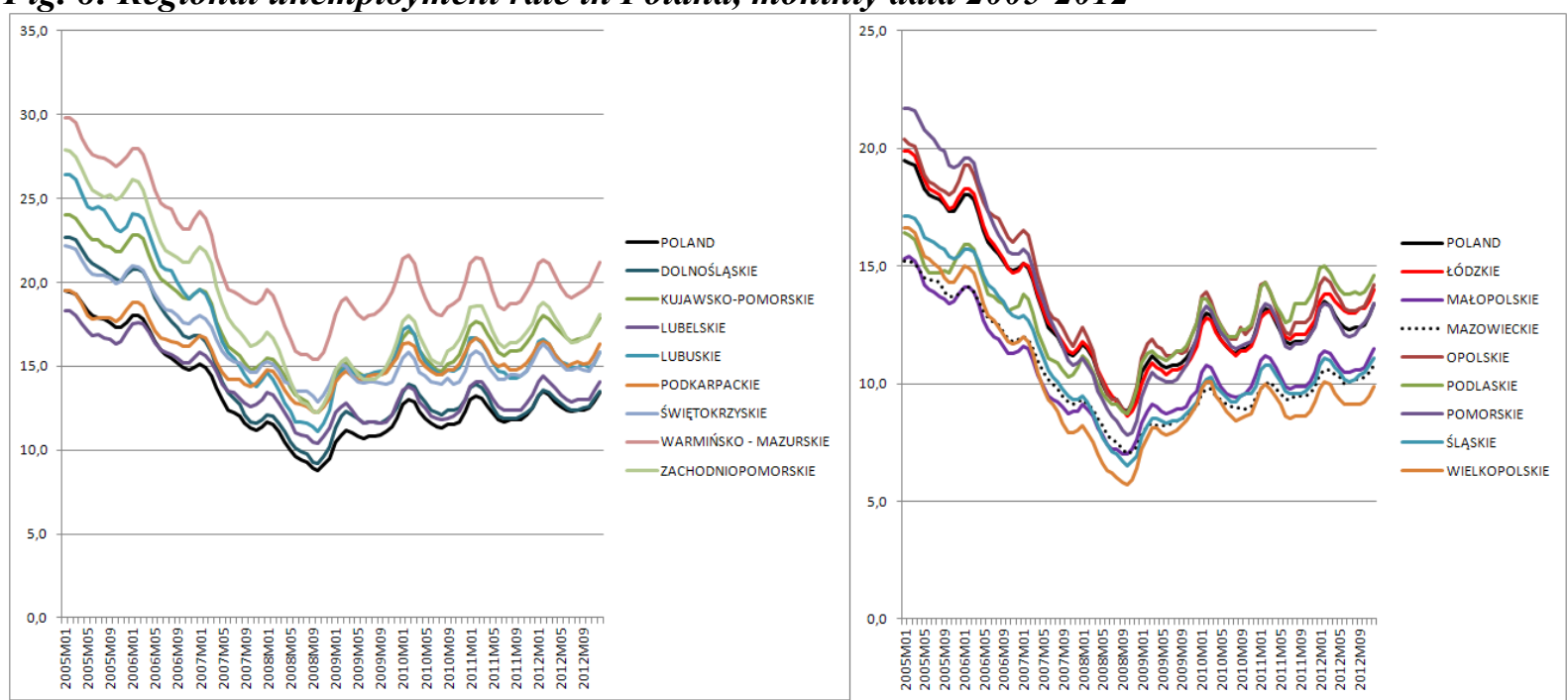

Source: Ministry of Labour and Social Policy of the Republic of Poland

Labour market development in Poland was similar as in the Slovak Republic - initial high unemployment rate was significantly reduced. When the economic crisis appeared the unemployment rate rose quickly. However, this increase was not as remarkable as in the case of the Czech Republic and Slovakia. An explanation could be given by development of real gross domestic product - Poland was one of few countries with only a slight economic downturn. Nevell [28] argues that the regional pattern of unemployment persisted.

Fig. 9: The minimum and maximum range of regional unemployment rate in Poland

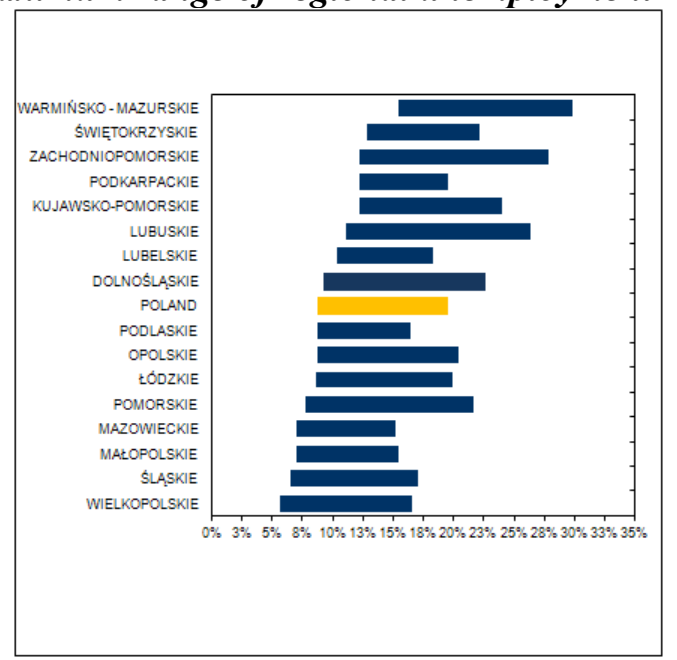

Source: Ministry of Labour and Social Policy of the Republic of Poland

\section{Conclusion}

In this article we examined the evolution of regional disparities in selected Member States of the European Union between the years 2005 and 2012. We used the unemployment rate as the key indicator of labour market performance. It seems to be obvious that growing economies of the Visegrad countries recorded the significant decrease of the unemployment rate in all regions in the pre-crisis period which is a logical resulting of the growing phase of the business cycle and validation of general conclusions of the economic theory. The analysis also confirmed the link between the economic crisis and decreasing regional disparities - in other words it means that during the crisis regional disparities tend to disappear during the economic crisis. We found that development was same in three countries (Czech Republic, Poland and Slovakia). Development of Hungarian labour 
market performance was different due to economic problems in the pre-crisis period. The lowest unemployment rate was reached in the regions of the capitol cities. The highest unemployment rate close to $30 \%$ was found in some regions in Hungary, Poland and Hungary.

\section{Literatura}

[1] MUNTEAN, M.C., NISTOR, R. AND NISTOR,C. Competitiveness of Developing Regions in Romania. WSEAS Transactions on Business and Economics, vol. 7, no. 3, July 2010, pp. 252261.

[2] NEVELL, A. Regional Unemployment and Industrial Restructuring in Poland. IZA Discussion Paper No. 194, 2000.

[3] TVRDON, M. Impacts of the Global Economic Crisis on the European Labor Market Performance: the Case of Visegrad Group Countries. In Recent Advances in Business Administration - 5th WSEAS International Conference on Business Administration (ICBA'11). 2011, s. 38-43. Puerto Morelos: WSEAS Press. ISBN 978-960-474-269-1.

This research was financially supported by the Student Grant Competition SU within the project SGS/7/2012 "The influence of regional disparities on the business environment". 